\title{
PENGARUH CITRA MEREK DAN PERSEPSI KUALITAS TERHADAP LOYALITAS MEREK
}

\author{
Bayu Andika Dipura \\ Department of Management FEB UMM \\ Email: bayu.dipura@gmail.com
}

\begin{abstract}
This research aims to examine effects of brand image and perceived quality simultaneously and partially on brand loyalty Indosat card users. Methods of data collection using questionnaires. The sample size consisted of 125 respondents taken by accidental sampling. Data were analyzed using a range of scales and ordinary least squares (OLS).

The results show the brand image and perceived quality have influence simultaneously and partially on brand loyalty with the determination coefficient is $71,9 \%$. This means that if the brand image and perceived quality, brand loyalty is high then high, and vice versa. Variable brand image dominant influence on brand loyalty Indosat card users.
\end{abstract}

Keywords: brand image, perceived quality, brand loyalty

\section{PENDAHULUAN}

Kebutuhan akan teknologi, baik itu teknologi informasi maupun komunikasi di era globalisasi seperti saat ini sangatlah tinggi, mulai dari golongan menengah ke bawah hingga golongan menengah ke atas. Semua individu sangat membutuhkan teknologi disamping untuk mempercepat perkembangan dan/ atau meningkatkan pembangunan baik pembangunan individu maupun kelompok. Perkembangan teknologi yang saat ini sangat cepat adalah teknologi komunikasi, yang menghadirkan beragam pilihan bentuk teknologi dan kecanggihannya.

Persaingan yang ketat dalam industri telekomunikasi seluler, khususnya produk prabayar GSM menyebabkan operator berlomba adu strategi untuk merebut hati pelanggan, tidak hanya melakukan penetrasi pasar tetapi juga meningkatkan layanan dalam hal: luasnya jaringan, kualitas jaringan, inovasi produk, pelayanan pelanggan dan tarif kompetitif. Hal ini akan memberikan harapan kepada pelanggan, namun apa yang diterima belum tentu sesuai dengan harapan. Sebagian dari mahasiswa Fakultas Ekonomi Universitas Muhammadiyah Malang adalah pengguna kartu Indosat yang mempunyai harapan terhadap kualitas kartu Indosat.

PT. Indosat sebagai salah satu operator telekomunikasi terkemuka di Indonesia melakukan transformasi bisnis utamanya dari penyelenggara SLI ke penyelenggara jaringan dan jasa telekomunikasi lengkap dan terpadu. Beberapa jenis layanan seluler yang disediakan oleh PT. Indosat saat ini adalah Matrik, Mentari, IM3 Smart dan IM3 Bright 
(Hamzah, 2007). Indosat sudah menerapkan teknologi yang dinamakan Indosat Care untuk ketepatan dan pelayanan, yaitu Customer Relationship Management yang mengintegrasikan seluruh call center brand dengan divisi-divisi yang berhubungan dengan pelayanan pengembangan teknologi selanjutnya yang dikembangkan adalah video call untuk call center.

Hal yang tidak mudah bagi Indosat untuk mempertahankan posisi yang telah dimiliki IM3 di tengah persaingan bisnis jasa telekomunikasi selular GSM yang semakin kompetitif dan ketat. Kondisi ini mengharuskan PT Indosat membuat strategi untuk mempertahankan eksistensi dan menjadi leader market. Salah satu strategi yang dapat dilakukan adalah menciptakan loyalitas merek pada konsumen. Namun, ini bukanlah tugas mudah, mengingat perubahanperubahan dapat terjadi setiap saat, baik perubahan pada diri konsumen, seperti selera maupun aspek-aspek psikologis, sosial, dan kultural konsumen, maupun persaingan kompetitor lain.

Loyalitas merek (brand loyalty) merupakan ukuran sejauh mana konsumen menunjukkan sikap positif terhadap suatu merek, mempunyai komitmen pada merek tersebut, dan berniat untuk terus membelinya dimasa depan (Mowen dan Minor, 2002:108). Mendapatkan dan mempertahankan loyalitas konsumen pada suatu merek sangat mempengaruhi lapisan dasar perusahaan daripada kampanye iklan, program pemasaran. Para konsumen yang berbalik arah akan merugikan perusahaan sehingga dengan cepat menyeret perusahaan pada kekacaubalauan, sedangkan perusahaan yang secara aktif mencurahkan aliran inovasi pada penciptaan loyalitas konsumen akan mengalami penguatan basis konsumen secara konsisten dan perusahaan tersebut akan terus eksis dan berkembang.

Loyalitas konsumen pada suatu merek dipengaruhi oleh banyak faktor. Hardiawan dan Mahdi (2005:13-14) mengungkapkan faktor-faktor yang mempengaruhi loyalitas konsumen pada suatu merek adalah citra merek. Karsono (2007:98) menyatakan bahwa konsumen akan mempersepsikan pendapat orang lain yang mengatakan bahwa jika citra suatu merek baik, maka konsumen akan merasa lebih aman ketika menggunakan merek dari perusahaan tersebut. Aydin dkk (2005) menyatakan bahwa sikap secara fungsional berhubungan dengan minat, dimana memprediksikan suatu tingkah laku. Konsekuensinya citra merek sebagai sikap berpengaruh terhadap minat seperti customer loyalty (Karsono, 2007:98).

Faktor selanjutnya yang mempengaruhi loyalitas adalah perceived quality (persepsi kualitas). Persepsi kualitas, mencerminkan persepsi pelanggan terhadap keseluruhan kualitas atau keunggulan suatu produk atau jasa layanan berkenaan dengan maksud yang diharapkan. Konsumen akan menyukai dan mungkin menjadi loyal terhadap produk dengan persepsi kualitas yang tinggi. Persepsi kualitas merupakan komponen dari nilai merek, karena itu, kualitas persepsi kualitas yang 
tinggi akan mendorong pelanggan untuk memilih merek tertentu dibanding merek pesaing lainnya. Bila persepsi terhadap kualitas merek bisa di terima oleh konsumen maka akan meningkatkan loyalitas merek.

Dengan demikian perumusan masalah dalam penelitian sebagai berikut :

Apakah citra merek dan persepsi kualitas berpengaruh secara simultan terhadap loyalitas merek pengguna kartu Indosat?, Apakah citra merek dan persepsi kualitas berpengaruh secara parsial terhadap loyalitas merek pengguna kartu Indosat?, Diantara citra merek dan persepsi kualitas manakah yang dominan pengaruhnya terhadap loyalitas merek pengguna kartu Indosat?

Tujuan penelitiannya adalah :

Menguji pengaruh citra merek dan persepsi kualitas secara simultan terhadap loyalitas merek pengguna kartu Indosat. Menguji pengaruh citra merek dan persepsi kualitas secara parsial terhadap loyalitas merek pengguna kartu Indosat. Menguji citra merek dan persepsi kualitas yang dominan pengaruhnya terhadap loyalitas merek pengguna kartu Indosat.

\section{TINJAUAN PUSTAKA}

Penelitian yang dilakukan oleh Angriawan (2011) menyimpulkan brand image, service quality, dan perceived quality berpengaruh secara signifikan terhadap brand loyalty. Variabel brand image berpengaruh dominan terhadap brand loyalty. Sedangkan Penelitian kedua yang mendukung penelitian ini adalah penelitian yang dilakukan oleh Salim dan Dharmayanti (2014), menyimpulkan bahwa brand image dan perceived quality berpengaruh secara signifikan terhadap kepuasan pelanggan. Kepuasan pelanggan berpengaruh secara signifikan terhadap loyalitas pelanggan, dan brand image dan perceived quality berpengaruh secara tidak langsung terhadap loyalitas pelanggan. Hal ini dapat dijelaskan bahwa image sebuah brand dapat membuat pelanggan bersikap positif terhadap produk tersebut, sehingga pelanggan menjadi loyal.

Citra merek adalah sekumpulan asosiasi merek yang terbentuk dan melekat di benak konsumen. Konsumen yang terbiasa menggunakan merek tertentu cenderung memiliki konsistensi terhadap citra merek. Citra merek ialah persepsi dan keyakinan yang dilakukan oleh konsumen, seperti tercermin dalam asosiasi yang terjadi dalam memori konsumen (Kotler dan Keller, 2009:346). Sedangkan Kotler (2007:346) menyatakan bahwa citra merek ialah persepsi dan keyakinan yang dilakukan oleh konsumen, seperti tercermin dalam asosiasi yang terjadi dalam memori konsumen.

Kotler dan Keller (2009:56) menyatakan bahwa pengukur citra merek dapat dilakukan berdasarkan pada aspek sebuah merek yaitu:

Kekuatan (strengthness) Yang termasuk pada sekelompok kekuatan (strength): penampilan fisik, keberfungsian semua fasilitas produk, harga produk, maupun fasilitas pendukung dari produk tersebut.

Keunikan (uniqueness) Yang termasuk dalam kelompok unik ini adalah variasi layanan, variasi harga, maupun penampilan atau nama dari 
sebuah merek dan fisik produk itu sendiri

Favorable Yang termasuk dalam kelompok favorable ini antara lain kemudahan merek produk diucapkan serta kemampuan merek untuk tetap diingat oleh pelanggan maupun kesesuaian antara kesan merek dibenak pelanggan dengan citra yang diinginkan perusahaan atas merek yang bersangkutan.

Aaker dalam Durianto, dkk (2004:16), persepsi pelanggan terhadap keseluruan kualitas atau keunggulan suatu produk atau jasa layanan berkaitan dengan maksud yang diharapkan. Secara obyektif kesan kualitas tidak dapat diterapkan karena berkaitan dengan persepsi dan tingkatan kepentingan bagi konsumen. Knapp (2002:17), menambahkan bahwa tidak peduli bagaimana seseorang memiliki untuk menilai kualitas yang dirasakan, karena kualitas akhirnya ditentukan oleh seberapa baik pelanggan merasakannya.

Persepsi kualitas mencerminkan perasaan pelanggan secara menyeluruh mengenai suatu merek. Untuk memahami persepsi kualitas suatu merek diperlukan pengukuran terhadap dimensi yang terkait dengan karakteritik produk. Durianto, dkk (2007:98) menyatakan bahwa persepsi kualitas dibagi menjadi tujuh, yaitu:

Kinerja (performance)

Performance merupakan karateristik utama yang dipertimbangkan pelanggan dalam membeli barang tersebut.

Kemudahan pelayanan (service ability) Mencerminkan kemampuan memberikan pelayanan pada produk tersebut berkaitan kemudahan dalam memberikan layanan.

Daya Tahan (durability) Mencerminkan umur ekonomis dari produk tersebut berupa ukuran daya atau masa pakai produk barang.

Keandalan (reliability) Konsistensi dari kinerja yang dihasilkan suatu produk dari satu pembelian ke pembelian berikutnya.

Fitur (features) Bagian-bagian tambahan dari produk (fitur) yang berguna untuk menambah fungsi dasar berkaitan dengan pilihanpilihan produk dan pengembangannya.

Kesesuaian dengan spesifikasi (conformance with spesifications) Pandangan mengenai kualitas proses manufaktur (tidak ada cacat produk) sesuai dengan spesifikasi yang yang telah ditentukan dan teruji. Dimensi ini juga bisa diartikan sebagai kesesuaian produk terhadap spesifikasi yang telah ditetapkan sesuai dengan keinginan konsumen.

Hasil akhir (fit and finish) Mengarah pada kualitas yang dirasakan yang melibatkan enam dimensi sebelumnya.

Aaker (2002:8) mendefinisikan brand loyalty sebagai " $A$ measure of the attachment that a costumer has a brand". Loyalitas merek menunjukkan adanya suatu ikatan antara pelanggan dengan merek tertentu dan ini sering kali ditandai dengan adanya pembelian ulang dari pelanggan. Mowen dan Minor (2002:108), mendefinisikan loyalitas merek sebagai sejauh mana seorang pelanggan menunjukkan sikap positif terhadap suatu merek, mempunyai komitmen pada merek tertentu dan beniat untuk terus membelinya di masa depan. Loyalitas merek adalah 
ukuran dari kesetiaan konsumen terhadap merek (Rangkuti, 2004:60). Ballester dan Aleman (2005:191), atribut loyalitas merek dibentuk oleh indikator:

Puas dengan layananan yang diberikan, Membeli secara terus menerus ketika membutuhkannya, Merekomendasikan kepada keluarga, Merekomendasikan kepada teman saya Menggunakan layanan lainnya yang ditawarkan

Persepsi pelanggan terhadap merek didapat melalui proses pembelajaran dan proses pemikiran yang cukup matang melalui keputusan pembeliannya terhadap suatu produk. Haubl (1996) mengatakan bahwa citra merek berpengaruh langsung terhadap tingkat minat beli terhadap suatu produk.

Adapun citra yang dibangun Indosat saat ini adalah memiliki sinyal kuat. Upaya-upaya yang dilakukan Indosat untuk tetap mendapat julukan sebagai seluler yang memiliki sinyal kuat, pada Juli 2007 Indosat kembali mengkampanyekan Sinyal Kuat Indosat, 'Kemana-mana Sinyal Kuat Indosat Dimana-mana' yang dilaksanakan di Yogyakarta (Ramli, 2007). Hal ini sesuai dengan penelitian yang dilakukan oleh Angriawan (2011) menyimpulkan citra merek berpengaruh secara signifikan terhadap loyalitas merek. Hasil penelitian ini diperkuat oleh penelitian yang dilakukan oleh Upamannyu, dkk (2014) menyatakan bahwa citra merek berpengaruh positif dan signifikan terhadap loyalitas merek

Persepsi kualitas merupakan salah satu strategi pemasaran terpenting dalam mempertahankan keunggulan kompetitif perusahaan melalui loyalitas merek (Ravald \& Gronroos, 1996). Slater (1997) menyatakan bahwa persepsi kualitas adalah hal penting dalam pemahaman perilaku konsumen, karena persepsi konsumen tentang kualitas berpengaruh terhadap keputusan pembelian mereka yang pada akhirnya mampu menciptakan loyalitas merek.

Memiliki pelanggan semua kalangan dan mampu memberikan layanan komunikasi yang lebih baik merupakan persepsi kualitas yang dimiliki Indosat yang akan berpengaruh terhadap loyalitas merek (Ramli, 2007). Sebagai satu strategi untuk memiliki persepsi kualitas dimata pelanggan, Indosat meluncurkan program poin plus-plus yang tujuannya membangun loyalitas pelanggan terhadap merek dari PT. Indosat. Hal ini sesuai dengan penelitian yang dilakukan oleh Angriawan (2011) menyimpulkan persepsi kualitas berpengaruh secara signifikan terhadap loyalitas merek. Hasil penelitian ini diperkuat oleh penelitian yang dilakukan oleh Dib dan Alhaddad (2014) menyatakan bahwa persepsi kualitas berpengaruh positif dan signifikan terhadap loyalitas merek

Berdasarkan teori dan hasil penelitian terdahulu yang diuraikan, maka dapat digambarkan kerangka pemikiran dalam penelitian ini seperti terlihat pada gambar 1 berikut ini:

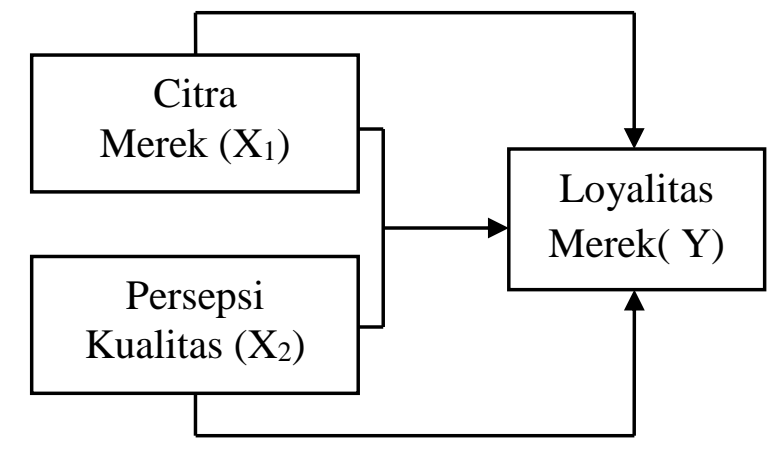




\section{Gambar 1}

Gambar di atas menunjukkan bahwa:

Terdapat pengaruh secara simultan antara variabel citra merek dan persepsi kualitas terhadap loyalitas merek pengguna kartu Indosat, Terdapat pengaruh secara parsial antara variabel citra merek dan persepsi kualitas terhadap loyalitas merek pengguna kartu Indosat. Diduga bahwa variabel citra merek yang dominan berpengaruh terhadap loyalitas merek pengguna kartu Indosat.

\section{METODE PENELITIAN}

Lokasi penelitian ini dilaksanakan pada Mahasiswa Fakultas Ekonomi Universitas Muhammadiyah Malang. Lokasi ini dipilih guna mendapatkan responden yang sesuai dengan yang diinginkan oleh peneliti.

Jenis penelitian yang digunakan adalah survey yaitu mengambil sampel dari suatu populasi dengan menggunakan kuesioner sebagai alat pengumpulan data yang pokok.

Sampel dalam penelitian ini adalah 125 orang. Teknik sampling yang digunakan dalam penelitian ini adalah accidental sampling, yaitu siapa saja yang secara kebetulan bertemu dengan peneliti dapat digunakan sebagai sampel bila orang yang ditemui cocok dan memenuhi kriteria sebagai sumber data.

Teknik pengumpulan data yang dilakukan adalah kuesioner. Setelah data terkumpul tahap selanjutnya adalah mengklarifikasi dan melakukan analisis data dengan menggunakan analisis regresi linier berganda, uji F, uji t, dan R Square.
Adapun persamaan analisa regresi linier berganda adalah sebagai berikut :

$$
Y=\alpha+\beta_{1} X_{1}+\beta_{2} X_{2}+\varepsilon t
$$

$$
\begin{aligned}
& \text { Keterangan: } \\
& \text { Y : loyalitas merek } \\
& \alpha \quad \text { : intersep/konstanta } \\
& \beta_{1}, \beta_{2}: \text { koefisien regresi } \\
& \mathrm{X}_{1} \text { : citra merek } \\
& \mathrm{X}_{2} \text { : persepsi kualitas } \\
& \text { e : error term } \\
& \mathrm{t} \quad \text { : time series }
\end{aligned}
$$

\section{HASIL PENELITIAN DAN PEMBAHASAN}

Berdasarkan hasil dari perhitungan citra merek dan persepsi terhadap loyalitas merek pengguna Kartu Indosat pada Mahasiswa Fakultas Ekonomi Universitas Muhammadiyah Malang dapat dilihat pada tabel 1 berikut ini:

Tabel 1. Hasil perhitungan variabel citra merek dan persepsi kualitas terhadap loyalitas merek

\begin{tabular}{lccc}
\hline \multicolumn{1}{c}{ Variabel } & $\Sigma$ & $\begin{array}{c}\text { Rata- } \\
\text { rata }\end{array}$ & $\begin{array}{c}\text { Kriteri } \\
\text { a }\end{array}$ \\
\hline Citra Merek & 125 & 498 & Tinggi \\
Persepsi & 125 & 511 & Tinggi \\
Kualitas & & 524 & Tinggi \\
\hline
\end{tabular}

Berdasarkan tabel di atas terlihat bahwa variabel citra merek memperoleh nilai rata-rata 498,5 yang berarti bahwa variabel citra merek memiliki pengaruh yang tinggi terhadap loyalitas merek pengguna kartu Indosat.

Berdasarkan tabel di atas juga terlihat bahwa variabel persepsi kualitas memperoleh nilai rata-rata 511,3 yang berarti bahwa variabel persepsi kualitas memiliki pengaruh 
yang tinggi terhadap loyalitas merek pengguna kartu Indosat.

Berdasarkan tabel di atas juga terlihat bahwa variabel loyalitas merek memperoleh nilai rata-rata 524,8, hal ini menunjukkan bahwa mayoritas pengguna kartu Indosat merasa tidak hanya menggunakan layanan telpon dan SMS tetapi juga menggunakan layanan lainnya yang ditawarkan Indosat.

Berdasarkan hasil analisis regresi linear berganda, bahwa citra merek dan persepsi kualitas secara simultan dan parsial terhadap loyalitas merek pengguna Kartu Indosat pada Mahasiswa Fakultas Ekonomi Universitas Muhammadiyah Malang dapat dilihat pada tabel 2 berikut ini:

Tabel 2. Hasil perhitungan analisis regresi linier berganda variabel citra merek dan persepsi kualitas terhadap loyalitas merek

\begin{tabular}{|c|c|c|c|}
\hline Variabel & $\begin{array}{c}\text { Koefisi } \\
\text { en } \\
\text { Regresi }\end{array}$ & $\begin{array}{l}\text { Simpang } \\
\text { an Baku }\end{array}$ & $t_{\text {hitung }}$ \\
\hline Citra merek & 0,412 & 0,056 & 7,315 \\
\hline $\begin{array}{l}\text { Persepsi } \\
\text { kualitas }\end{array}$ & 0,354 & 0,060 & 5,924 \\
\hline \multicolumn{4}{|l|}{$\frac{\text { kualitas }}{\text { Constant }}$} \\
\hline \multicolumn{2}{|c|}{ Adjusted R Square } & \multicolumn{2}{|r|}{0,719} \\
\hline \multicolumn{2}{|c|}{ Koefisien Korelasi (R) } & \multicolumn{2}{|c|}{ : 0,848} \\
\hline \multicolumn{2}{|l|}{$\mathrm{F}_{\text {hitung }}$} & \\
\hline
\end{tabular}

Hasil perhitungan analisis regresi linier berganda yang dilakukan menunjukkan pengaruh variabel independent terhadap variabel dependent adalah tinggi. Hal tersebut dapat dilihat pada nilai Adjusted $R$ Square yaitu sebesar 0,719.

Dengan demikian berarti bahwa citra merek dan persepsi kualitas dipengaruhi oleh loyalitas merek sebesar $71,9 \%$ sedangkan sisanya $28,1 \%$ dijelaskan oleh variabel- variabel lain di luar model yang tidak dijelaskan dalam penelitian ini.

Berdasarkan pada hasil analisis yang telah dilakukan, maka persamaan regresi yang terbentuk adalah sebagai berikut:

$$
\begin{gathered}
\mathrm{Y}=2,435+0,412 \mathrm{X} 1+0,354 \mathrm{X} 2 \\
+\mathrm{C}
\end{gathered}
$$

Dari hasil di atas di peroleh nilai konstanta sebesar 2,649,

Dari persamaan di atas, dapat dijelaskan sebagai berikut :

$\mathrm{Y}=2,435$ memberikan arti bahwa citra merek dan persepsi kualitas berpengaruh positif terhadap loyalitas merek. Hal ini berarti apabila citra merek dan persepsi kualitas meningkat maka loyalitas merek terhadap kartu Indosat akan mengalami peningkatan.

$\mathrm{b}_{1}=0,412$ memberikan arti bahwa citra merek $\left(\mathrm{X}_{1}\right)$ berpengaruh positif terhadap loyalitas merek. Hal ini berarti apabila citra merek yang terdiri dari: kemasan stater pack kartu Indosat menarik, kartu Indosat memiliki sinyal kuat, kartu Indosat memiliki fitur layanan yang lengkap, kualitas suara kartu Indosat jernih, voucher isi ulang kartu Indosat mudah diperoleh, dan kartu Indosat mudah diingat meningkat, maka loyalitas merek pada pengguna kartu Indosat akan mengalami peningkatan.

$\mathrm{b}_{2}=0,354$ memberikan arti bahwa persepsi kualitas $\left(\mathrm{X}_{2}\right)$ berpengaruh positif terhadap loyalitas merek. Hal ini berarti apabila persepsi kualitas yang terdiri dari: kartu Indosat memiliki jaringan luas yang menjangkau seluruh wilayah di 
Indonesia, kartu Indosat memberikan tarif telepon, internet serta SMS dengan harga terjangkau, pelayanan call center Indosat baik, operator Indosat cepat tanggap menanggapi keluhan pelanggan, teknologi Indosat terdepan, dan kartu Indosat mempunyai jaminan SMS, MMS serta akses WhatsApp yang cepat meningkat, maka loyalitas merek pada pengguna kartu Indosat akan mengalami peningkatan.

Dengan pengujian uji $\mathrm{F}$ diperoleh nilai F hitung sebesar 156,285, sedangkan nilai $F_{\text {tabel }}$ sebesar 3,07, karena $F_{\text {hitung }}>F_{\text {tabel }}$ maka hipotesis nol (Ho) di tolak dan Hipotesa alternatif (H1) diterima. Hal ini menunjukkan bahwa variabel independen yang meliputi citra metrek $\left(\mathrm{X}_{1}\right)$, dan persepsi kualitas $\left(\mathrm{X}_{2}\right)$ secara simultan atau bersamasama mempengaruhi variabel loyalitas merek (Y) secara signifikan

Dengan menggunakan test dua arah, derajat bebas 50 dan taraf nyata $5 \%$, diperoleh nilai $t_{\text {tabel }}$ sebesar 1,979. Untuk menilai apakah $\mathrm{H} 0$ yang diterima ditolak, ditentukan kriteria sebagai berikut:

Jika $t_{\text {hitung }}>\mathrm{t}_{\text {tabel, }}$ maka H0 ditolak atau $\mathrm{H} 1$ diterima.

Jika $t_{\text {hitung }} \leq \mathrm{t}_{\mathrm{abel}}$, maka $\mathrm{HO}$ diterima atau $\mathrm{H} 1$ ditolak.

Dilihat dari thitung sebesar 7,315. Karena nilai t-hitung $>$ t-tabel, maka $\mathrm{H}_{0}$ ditolak dan $\mathrm{H}_{1}$ diterima. Dengan demikian dapat dikatakan bahwa variabel citra merek $\left(\mathrm{X}_{1}\right)$ adalah berpengaruh signifikan pada taraf nyata $(\alpha)=0,05$ dengan tingkat kepercayaan $95 \%$, dan nilai persepsi kualitas diperoleh $t_{\text {hitung }}$ sebesar 5,924. Karena nilai t-hitung $>$ t-tabel, maka $\mathrm{H}_{0}$ ditolak dan $\mathrm{H}_{1}$ diterima. Dengan demikian dapat dikatakan bahwa variabel persepsi kualitas $\left(\mathrm{X}_{2}\right)$ adalah berpengaruh signifikan pada taraf nyata $(\alpha)=0,05$ dengan tingkat kepercayaan $95 \%$.

Berdasarkan hasil standardized coefficients beta menunjukkan bahwa variabel citra merek $\left(\mathrm{X}_{1}\right)$ mempunyai nilai koefisien beta yang paling besar diantara variabelvariabel lainnya yaitu sebesar 0,505. Hal ini berarti variabel citra merek $\left(\mathrm{X}_{1}\right)$ dinyatakan variabel yang dominan berpengaruh terhadap loyalitas merek pengguna kartu Indosat pada Mahasiswa Fakultas Ekonomi Universitas Muhammadiyah Malang. Maka hipotesis ketiga yang menyatakan bahwa variabel citra merek berpengaruh dominan terbukti.

Variabel citra merek, indikator yang dipersepsikan tinggi nilainya oleh responden (yang ditunjukkan dengan nilai rata-rata tertinggi) adalah mudah diingat, indikator dengan nilai tertinggi kedua adalah voucher isi ulang, indikator dengan nilai tertinggi ketiga adalah kualitas suara, indikator dengan nilai tertinggi keempat adalah fitur layanan yang lengkap, indikator dengan nilai tertinggi kelima adalah sinyal kuat, dan indikator dengan nilai tertinggi keenam adalah kemasan stater pack. Pada variabel persepsi kualitas, indikator yang dipersepsikan tinggi nilainya oleh responden (yang ditunjukkan dengan nilai rata-rata tertinggi) adalah jaminan SMS, MMS, indikator dengan nilai tertinggi kedua adalah internet cepat dan call center, indikator dengan nilai tertinggi ketiga adalah cepat tanggap, indikator dengan nilai tertinggi keempat adalah jaringan 
luas, dan indikator dengan nilai tertinggi kelima adalah teknologi.

Sedangkan pada variabel loyalitas merek, indikator yang dipersepsikan sangat tinggi nilainya oleh responden (yang ditunjukkan dengan nilai ratarata tertinggi) adalah menggunakan layanan lainnya, indikator dengan nilai sangat tinggi kedua adalah membeli terus menerus, indikator dengan nilai tertinggi ketiga adalah puas dengan layanan, indikator dengan nilai tertinggi keempat adalah merekomendasikan pada teman, dan indikator dengan nilai tertinggi kelima adalah merekomendasikan pada keluarga.

Citra merek positif yang didapat oleh seorang konsumen akan berpengaruh terhadap loyalitas merek. Ketika konsumen memikirkan sebuah merek memiliki citra yang bagus, maka hal ini turut mempengaruhi persepsi kualitas yang akan didapat. Persepsi kualitas didasarkan pada penilaian konsumen terhadap atribut dari merek yang memberikan arti terhadap konsumen berdasarkan persepsi mereka. Konsumen yang mendapatkan kualitas yang sesuai dengan apa yang diharapkan, cenderung untuk menjadi loyal yang ditunjukkan dengan pembelian ulang terhadap suatu produk. Secara praktis dapat disimpulkan bahwa ketika citra merek yang dipandang konsumen positif, maka konsumen akan mempersepsikan merek produk tersebut berkualitas, merek yang mampu memberikan kualitas seperti yang diharapkan oleh konsumen akan menjadikan konsumen setia ataupun loyal terhadap merek.

Hasil penelitian ini sesuai dengan penelitian yang dilakukan oleh
Angriawan (2011) yang menyimpulkan bahwa brand image, service quality, dan perceived quality berpengaruh secara simultan terhadap brand loyalty. Hasil penelitian ini juga sejalan dengan penelitian yang dilakukan oleh Kayaman dan Arasli (2007), Hasil temuan menunjukkan bahwa citra merek dan persepsi kualitas berpengaruh positif dan signifikan terhadap loyalitas merek.

Dari hasil penelitian tersebut dapat disimpulkan bahwa kemampaun variabel citra merek dan persepsi kualitas dapat dikatakan baik, namun demikian masih ada variabel-variabel lainnya yang harus diperhatikan dalam mengukur loyalitas merek. Secara garis besar dapat dijelaskan bahwa citra merek dan persepsi kualitas yang dilakukan oleh pihak perusahaan seluler Indosat mampu memberikan kontribusi yang besar terhadap penciptaan loyalitas merek terhadap produk yang mereka tawarkan, hal ini akan berpengaruh positif bagi kelangsungan bisnis operator telekomunikasi khususnya provider Indosat

Hasil penelitian ini menunjukkan bahwa terdapat pengaruh antara citra merek terhadap terhadap loyalitas merek pengguna kartu Indosat. Hasil penelitian ini sejalan dengan teori yang dikemukakan oleh Schiffman dan Kanuk (2010:141) yang menyatakan bahwa citra merek yang berbeda dan unik merupakan hal yang paling penting, karena produk semakin kompleks dan pasar semakin penuh, sehingga konsumen akan semakin bergantung pada citra merek daripada atribut merek yang sebenarnya untuk mengambil keputusan pembelian. Hal inilah 
yang membuat merek-merek yang dipandang konsumen sebagai terbaik dalam kategorinya adalah merekmerek yang mendulang keuntungan paling banyak, paling dicari konsumen dan memiliki pelanggan dengan loyalitas tinggi (Tybout dan Calkins, 2005:2). Citra merek yang positif dan pengalaman terhadap merek produk yang memuaskan akan menimbulkan rasa suka dan perasaan positif lainnya dalam diri konsumen, hal ini yang kemudian mempengaruhi keputusan konsumen untuk mempertahankan penggunaan produk dengan merek tersebut dan menunjukkan komitmen pada merek tersebut (loyalitas merek).

Hasil penelitian ini sesuai dengan penelitian yang dilakukan oleh Upamannyu, dkk (2014) menyatakan bahwa brand image berpengaruh positif dan signifikan terhadap loyalitas merek. Kayaman dan Arasli (2007) menyatakan bahwa untuk membangun loyalitas merek dibutuhkan citra merekyang baik.

Hasil penelitian ini menunjukkan bahwa terdapat pengaruh antara persepsi kualitas terhadap terhadap loyalitas merek pengguna kartu Indosat. Dalam penelitian ini pengguna kartu Indosat yang menilai bahwa persepsi kualitas dalam hal jaringan luas yang menjangkau seluruh wilayah di Indonesia, tarif telepon, internet serta SMS dengan harga terjangkau, pelayanan call center yang baik serta cepat tanggap menanggapi keluhan pelanggan, teknologi terdepan, dan jaminan SMS, MMS serta akses WhatsApp yang cepat sesuai dengan keinginan pengguna kartu Indosat.

Hasil ini menunjukkan bahwa dengan semakin ketatnya jaringan operator seluler, ada kompetitor lama dan kompetitor baru, Indosat tetap mampu sebagai jaringan terkemuka di Indonesia dengan menghadirkan produk inovatif yang melayani komunikasi seluler di Indonesia dengan tarif murah, jangkauan (coverage) dan didukung sinyal kuat, layak jika Indosat menjadi jaringan seluler terkemuka di Indonesia

Penelitian ini sejalan dengan teori yang dikemukakan oleh Ravald \& Gronroos (1996) yang menyatakan bahwa persepsi kualitas merupakan salah satu strategi pemasaran terpenting dalam mempertahankan keunggulan kompetitif perusahaan melalui loyalitas merek. Sedangkan menurut Slater (1997), persepsi kualitas adalah hal penting dalam pemahaman perilaku konsumen, karena persepsi konsumen tentang kualitas berpengaruh terhadap keputusan pembelian mereka yang pada akhirnya mampu menciptakan loyalitas merek.

Hasil penelitian ini sesuai dengan penelitian yang dilakuan oleh Dib dan Alhaddad (2014), yang menyatakan bahwa persepsi kualitas berpengaruh signifikan terhadap brand loyalty. Hasil penelitian ini diperkuat denga penelitian yang dilakukan Kayaman dan Arasli (2007) bahwa persepsi kualitas berpengaruh positif dan signifikan terhadap loyalitas merek.

Variabel citra merek merupakan variabel yang yang paling dominan berpengaruh terhadap loyalitas merek pada pengguna kartu Indosat. Hal tersebut dapat disimpulkan bahwa dengan beragam kemudahan dan manfaat yang ditawarkan, Indosat berharap pelanggannya dapat memperoleh lebih banyak 
kemudahan dan keleluasaan dalam berkomunikasi.

\section{SIMPULAN}

Berdasarkan hasil analisis dan pembahasan, maka dapat ditarik kesimpulan sebagai berikut:

Secara bersama-sama variabel citra merek dan persepsi kualitas berpengaruh positif dan signifikan terhadap loyalitas merek. Hal ini berarti semakin kuat citra merek dan persepsi kualitas maka loyalitas merek pengguna kartu Indosat semakin tinggi, sebaliknya semakin lemah citra merek dan persepsi kualitas maka loyalitas merek pengguna karti Indosat semakin rendah.

Citra merek berpengaruh positif dan signifikan terhadap loyalitas merek pengguna kartu Indosat. Karena konsumen pengguna kartu indosat mempersepsikan Indosat memiliko kemasan stater pack menarik, sinyal kuat, fitur layanan yang lengkap, kualitas suara jernih, voucher isi ulang kartu mudah diperoleh, dan mudah diingat. Menurut hasil penelitian persepsi kualitas berpengaruh positif dan signifikan terhadap terhadap loyalitas merek pengguna kartu Indosat terhadap keseluruhan kualitas atau keunggulan suatu produk yang mencakup jaringan luas yang menjangkau seluruh wilayah di Indonesia, tarif telepon, internet serta SMS dengan harga terjangkau, Pelayanan call center yang baik, serta cepat tanggap menanggapi keluhan pelanggan, teknologi Indosat terdepan, dan jaminan SMS, MMS serta akses WhatsApp yang cepat.

Variabel citra merek berpengaruh dominan terhadap loyalitas merek pada pangguna kartu Indosat. Hal tersebut dapat disimpulkan bahwa pengguna kartu Indosat menginginkan provider Indosat hendaknya terus meningkatkan perhatian terhadap pelanggan dan selalu melakukan maintenance terhadap kualitas jaringan dan perluasan coverage area agar komunikasi pelanggan semakin lancar. Semakin tinggi loyalitas yang diberikan oleh provider Indosat, maka semakin tinggi loyalitas pelanggan untuk selalu menggunakan kartu Indosat.

\section{DAFTAR PUSTAKA}

Aaker, David A. (2002). Ekuitas Merek. Jakarta: Mitra Utama

Angriawan, F. (2011). Pengaruh Brand Image, Service Quality, dan Perceived Quality Terhadap Brand Loyalty Kartu Prabayar GSM PT. Indosat Di Semarang. Skripsi. Universitas Dipenogoro Semarang

Aydin, S., G. Ozer and O. Arasil. (2005). Customer Loyalty and The Effect of Switching Costs as a Moderator Variable: A Case in Turkish Mobile Phone Market. Marketing Interlligence and Planning. 23(1): 89-103

Ballester, Elena Delgado., \& Aleman, Jose Luis Munuera. (2005). Does brand trust matter to brand equity?, Journal of Product \& Brand Management, 14(3): 187-196

Dib, Hayan., and Alhaddad, Abdullah.(2014). The Hierarchical Relationship Between Brand Equity Dimensions. European Scientific Journal, 10(28): 183-194 
Durianto, Darmadi., Sugiarto., \& Budiman, Lie Joko. (2004). Brand Equity Ten: Strategi Memimpin Pasar. Jakarta: Gramedia Pustaka Utama

Ekuitas dan Perilaku Merek. Jakarta: Gramedia Pustaka Utama

Hamzah, Amir. (2007). Analisis Experiential Marketing, Emotional Branding, dan Brand Trust Terhadap Loyalitas Merek Mentari. Manajemen Usahawan Indonesia, 36(6): 22-28

Hardiawan, F dan Mahdi, I. (2005). Faktor-faktor yang Mempengaruhi Kesetiaan Konsumen Terhadap Sebuah Merek Rokok (Studi pada Mahasiswa Fakultas Ekonomi Universitas Sebelas Maret Surakarta). Jurnal Fokus Manajerial, 3(1): 11-20

Haubl, G. (1996). A cross-national investigation of the effects of country of origin and brand name on the evaluation of a new

Kotler, Philip., dan Keller, Kevin Lane. (2009). Manajemen Pemasaran. Jakarta: Prenhallindo

Mowen, John C., \& Minor, Michael. (2002). Perilaku Konsumen. Jakarta: Erlangga

Ramli. (2007). Tambah Pelanggan di Saat Ketatnya Persaingan. Sijori Mandiri

Rangkuti, Freddy. (2004). The Power Of Brands: Teknik Mengelola Brand Equity dan Strategi Pengembangan Merek. Jakarta: Gramedia Pustaka Utama

Ravald, A., \& Granross, C. (1996). The Value Concept and Relationship Marketing. European Journal of Marketing, 30(2): 19-30
Durianto, Darmadi., Sugiarto., \& Sitinjak, Tony. (2007). Strategi Menaklukan Pasar Melalui Riset

car. International Marketing Review, 13(5): 76-97

Karsono. (2007). Peran Variabel Citra Perusahaan, Kepercayaan, dan Biaya Perpindahan yang Memediasi Pengaruh Kualitas Pelayanan Terhadap Loyalitas Pelanggan. Jurnal Bisnis dan Manajeman, 7(1): 93-110

Kayaman, Ruchan., and Arasli, Huseyin. (2007). Customer based brand equity: evidence from the hotel industry, Managing Service Quality. 17(1): 92-109

Knapp, Duanee. (2002). The Brand Mindset. Yogyakarta: Andi Offset

Kotler, Philip. (2007). Manajemen Pemasaran 1. Jakarta: Prenhallindo

Salim, Fanny Fibriyanti., \& Dharmayanti, Diah. 2014. Pengaruh Brand Image dan Perceived Quality Terhadap Kepuasan dan Loyalitas Pelanggan Mobil Toyota di Surabaya. Jurnal Manajemen Pemasaran Petra, 2(1): 1-8,

Schiffman, Leon G., \& Kanuk, Leslie Lazar. (2010). Consumers Behavior. 10th edition. New Jersey: Pearson Prentice Hall

Slater, S.F. (1997). Developing A Customer Value Based Theory of The Firm. Journal of The 
Academy of Marketing Science, 25 (3): 139-153

Tybout, A.M., \& Calkins, T. (2005). Kellog on Branding. New Jersey: John Wiley \& Sons, Inc
Upamannyu, Nischay K., Gulati, Chanda., \& Mathur, Garima. (2014). Effect of Brand Trust, Brand Image on Customer Brand Loyalty In FMCG Sector at Gwalior Region, Scholars World-IRMJCR, 2(2): 83-93. 